\title{
Lydia Kokkola
}

\section{Make Yourself At Home! \\ Adolescents in Search of the Queer Spaces of Home}

\begin{abstract}
Home' is often assumed to be a safe place, a place to which children can return after their adventures 'Away'. For many gay and lesbian teens, both fictional and in real life, however, the space they share with their family of origin is not a place where they can feel at home. The heterosexual family home is often so hostile to queerly desiring teens that they are forced to leave in search of a place where they can feel at home. The queer spaces they enter in their search are usually considered risky spaces - public spaces, urban spaces, the bar and the street - unhomely spaces. In these temporary, in-between spaces, the queerly desiring teens in the novels examined in this article form new family structures. Although all the Anglophone novels discussed end on moments of up-lift and hope for the future, the association of the queerly desiring youngster with risky spaces suggests that the queer teens are themselves unheimlich (uncanny).
\end{abstract}

Keywords: lesbian, gay, YA fiction, homelessness, queer geography, uncanny

\section{Home Spaces as Imagined Spaces}

Gaston Bachelard's seminal The Poetics of Space begins with a celebration of home: "all really inhabited space bears the essence of the notion of home" (5). Home spaces are infused with memories, emotions and desires making it unsurprising that home, like childhood, is infused with nostalgia. By focusing on the poetic space - the imaginative response to "spaces we love" (xxxi) - rather than with the physicality of the wardrobes, cellars and attics incorporated into his study - Bachelard highlights similarities between encounters with geographical locations and spaces encountered through literature. 
This is not to say that encounters with home spaces in literature are the same as physical spaces, but to draw attention to how these encounters inform one another.

Bachelard's insights into the affects that influence encounters with spaces assumes that 'home' is a place one loves in part because it "shelters day-dreaming, the house protects the dreamer, the house allows one to dream in peace" (6); home is where one can envisage ones desires. For many people, however, home is neither a place one loves nor a sheltered space in which to day dream.

Home, for many people, is taken for granted as a place of comfort, a retreat from the world, a place to be oneself. For many lesbians, gay men, bisexuals and trans identified people, however, home can be uncomfortable and alienating. (Browne, Lim and Brown, 3)

'Home' for many queer adolescents is so 'uncomfortable and alienating' that they leave the parental home in search of a home space which resembles those Bachelard celebrates: spaces where they are free to dream of someone they desire, of a community in which they are accepted. The numbers of queer teens who run away from the parental home in search of such queer spaces are supplemented with 'throwaways' - youths evicted from their homes by parents - to the extent that queer adolescents are estimated to be 7-10 times more likely than their heterosexual peers to experience homelessness (Rosario, Schrimshaw and Hunter, "Risk Factors").

This article resonates to Bachelard's conception of home as an imaginative space, and of the valence at play between literary and 'real' encounters at play as it investigates the spaces in which queer adolescent characters in Anglophone fiction for teens feel 'at home'. Bachelard's nostalgic presentation of home, like the happy, safe, childhood home that dominates children's literature, proffers an ideal from which the risky, queer spaces that provide havens for queerly desiring teens are measured. The literary texts I examine are drawn from a corpus of 200 Anglophone novels and short stories written 1945-2012 depicting sexually active adolescents. This corpus formed the basis for my study Fictions of Adolescent Carnality, which covered a wide range of topics related to adolescent sexuality. Forty of the narratives (from the U.S.A., Canada, Ireland, the U.K. and Australia) published 1969-2012 depicted a significant character who experienced same-sex desire. (There were also a few characters whose desires were queer in other ways (Kokkola, Fictions 95-170) but in this article I focus only on same-sex desire using 'queer' as an 
embracing term, even though it causes slight problems in defining queer spaces for reasons I shall explain shortly.) All 40 narratives depicted the adolescent coming out publically and/or the first experience of same-sex desire, and for all the characters the process was presented as being problematic. The same-sex desiring teens were forced to leave their home spaces - temporarily or permanently - in all but seven of the narratives (published fairly evenly between the late 1970s and today): being unhomed was the norm, not the exception. In Fictions of Carnality, I was concerned with how carnal desires were used to signal the transition into adulthood and did not address the geography of queer desires. Here I wish to redress that balance by summarizing what I found in the larger corpus, and illustrating my points with reference to just a handful of examples. My point is not that a handful of authors have chosen to depict the unwelcoming character of the (heterosexual) home for the queerly desiring teen, but rather to draw attention to how the notion of 'home' in these 40 Anglophone narratives consistently differs from the homes of heterosexual teens in the other 160 narratives. It is an invitation to scholars from other language backgrounds to compare how their national literatures differ from the corpus I present. The majority of this article examines the home-spaces of queer adolescents in the corpus, and concludes by considering how these home spaces affect our reading of the adolescents themselves.

\section{Queer Desires in Heterosexual Homes}

The queer child is typically raised by heterosexual parents ${ }^{1}$ who cannot pass on scripts to their offspring about how to be and do their queerness. The queer child is certainly not the only child for whom the lack of role modeling is an issue. Cross-racially adopted children, for instance, cannot turn to their parents for models about how to be and do their race (Bergquist; Kokkola, "Interpictorial Allusions"). The key difference being that cross-racially adopted children's parents have made a conscious, positive decision to adopt a child who is 'unlike' me. Heterosexual parents do not make a decision to raise queer children, and the reality that same-sex desire is often met with extreme opposition from within the home is reflected in literature for teens (Cart; Cart and Jenkins), and was also very evident in the 40 Anglophone narratives in my study. It was also clear that these narratives all sought to offer advice to young readers on how to be and do their queerness. 
In an interview with Michelle Anne Abate, the lesbian author Marijane Meaker (who publishes under the playful pseudonym, M. E. Kerr) compared same-sex desires with dwarfism. When writing her novel Little Little, Meaker explains that "I compared, in my mind, dwarfism to homosexuality because each group has no peers, and they're sort of isolated until they can find their own group, and nobody in their family can say to them, 'Oh, I went through that, too,' because they're unique and there's lots of parallels" (qtd. Abate, 192). The narratives in the corpus go some way towards explaining how teens whose orientations are not heterosexual 'can find their group'. From the teens' perspective, this is not an act of resistance; they are a vulnerable group searching for a place where they can feel at home. The act of 'finding' indicates that this is a spatial activity: the characters need to find queer spaces.

For Judith Halberstam, the term queer space "refers to the placemaking practices within postmodernism in which queer people engage and it also describes the new understandings of space enabled by the production of queer counterpublics" (6). That is, for Halberstam and a number of other queer geographers who focus exclusively on adult sexualities, defining a space as 'queer' is an act of resistance, a rejection of the heteronormative world. For the vulnerable, newly 'out' teen, the search for a queer space is not an act of defiance, simply a search for others who are 'like me'. Nevertheless, many parents perceive their child's same-sex desires and their search for others 'like me' as a form of rebellion, and so the search for a place in which to feel 'at home' is undertaken with a good deal of trepidation. The main problem both fictional and real adolescents face is that queer spaces are not easily visible: they are deliberately hidden from the heteronormative view.

Several of the novels address this problem by including characters who act as guides. A Time Before Me (2005) by Michael Perrone is set in the deep south of the U.S. in the 1990s. The protagonist, seventeen year old Mason, lives in the small town of Andrew Springs, Mississippi. He is delighted when he is cruised by a stranger, Daniel. Daniel takes Mason to a 'secret' bar - Bubba Joe's - outside Andrew Springs. The bar is, in reality, simply a barn. The men bring their own drinks and gather around using bales of straw as seats and tables. This temporary rearrangement of the physical environment is a typical feature of the queer spaces in the novels. Later in the novel, Mason moves to New Orleans where he is guided around more permanently fixed queer spaces - gay bars and drag cabarets - by Joey. A guide is needed first to find the spaces and then to model 
appropriate behavior when entering and leaving as well as whilst on either side of the space. The books I discuss are also guides for their readers: authors of GLBTQ fiction for teens often claim in interview that they are responding to the problems queer teenagers face (Kokkola, Fictions 95-6ff).

In Queer Phenomenology, Sara Ahmed notes that the expression 'sexual orientation' contains the idea that desire is, at least partly, a form of movement, of finding one's way. By foregrounding the concept of 'orientation', Ahmed suggests that "If orientation is a matter of how we reside in space, then sexual orientation might also be a matter of residence; of how we inhabit spaces as well as 'who' or 'what' we inhabit spaces with" (1). This idea of sexual orientation sits well with Michel de Certeau's notion of spatial practice (115). De Certeau compares the officially sanctioned view of spaces that appear on maps with the way people on the street use space. The latter "are walkers, Wandersmänner, whose bodies follow the thicks and thins of the urban 'text' they write without being able to read it" (93). They "make use of spaces that cannot be seen" (93) as they choose routes based on memories and desires that were never planned by those who designed the city. This is 'spatial practice': the use of spaces for purposes for which they were not planned, and because possibilities emerge that were not envisaged by the authorities: a barn becomes a bar, the woods beyond the lighted bar becomes a place to have sex. In this way, spatial practices can be a form of resistance as spaces can be created which resist regulation.

The borders between queer and heteronormative spaces are very carefully policed. Michel Foucault draws on de Certeau's notion of spatial practice to create the term heterotopia which describes these kinds of unseen spaces. Heterotopic spaces are not public spaces "to get in, one must have certain permission and make certain gestures" (Foucault, 26). The books model the gestures that are needed to enter queer spaces. The characters in the novels show how one must negotiate with bouncers at the entrances to queer spaces, and often with homophobes - self-proclaimed 'fag-bashers' - when entering or leaving the queer space. These negotiations are often foregrounded in the narratives. For instance, in Alasdair Duncan's Australian novel, Sushi Central (2003), the sexually experienced protagonist, Calvin, has some difficulties negotiating entry to 'The Beat' because, at fourteen, he is not old enough to enter a bar. Within the bar, he is safe to act upon his desires and picks up Anthony. But, upon leaving the bar to go to Anthony's home to have sex, his return to the heterosexual world is policed by the taxi driver. Although the boys 
are not attacked, the reactions of the taxi driver warn even the drug befuddled Calvin that he has left the temporary safe space of the bar. Neil, the protagonist of the first Irish teenage novel to feature a gay protagonist - Tom Lennon's When Love Comes to Town (2003) - is not so fortunate. Neil often lies to the person driving him to and from the gay district in Dublin, and a key event in the novel is that he is badly beaten upon leaving a gay bar.

None of the lesbian characters in the narratives faced this kind of physical threat but their parental homes were no less uncomfortable and alienating. In the first American novel to feature a lesbian protagonist, Rosa Guy's novel, Ruby (1976), Ruby's home space is dominated by her verbally and physically abusive father, Calvin. In the short periods when he is away, a passionate relationship between reticent, easily bullied Ruby and confident Daphne flourishes. On one occasion, Ruby starts to make love with Daphne, but the pair are interrupted by Calvin's unexpected return. Ruby literally pushes Daphne out of the family home and onto a window ledge to avoid being discovered. Ruby would rather risk Daphne's life than face her father's anger. The girls' relationship ends as result. Daphne's life-threatening movement as she hangs from the window sill is extreme, but queer adolescents are often forced out of their home environment into spaces that are associated with danger and risk. Ruby stays at home. That might seem like a safe space, but since it is a space associated with her father's aggression and has created a feeling of fear so great in her that she would rather risk her lover's life than his anger one has to question how welcoming this is. The novel ends with her father bringing the boyfriend he banished back into Ruby's life, signaling a forced return to heterosexuality. Ruby is too young to leave home. Like many other young queer teens, she must repress her same-sex desires if she wishes to stay in the parental home. The same was true of many other novels in the corpus (e.g. Tony in Levithan's Boy Meets Boy (2003), Neil in Lennon's When Love Comes to Town (2003) and John Ritchie in Ferris's Eight Seconds (2000)). Others were forcibly ejected from the family home (e.g. Holland in Peters's Keeping You a Secret (2003) which I discuss below). Upon leaving the family home, the spaces these queerly desiring teen characters seek are spaces that the majority population would consider risky.

\section{Queer Spaces as Risky, Liminal Spaces}

The spaces the queerly desiring teens seek in these Anglophone novels are characterized by their liminality and/or high levels of risk. 
Space is defined socially. Even spaces that appear physical, defined and unchanging are, in fact open to negotiation. Sexual geographers examine how sexual spaces and gendered behaviors are mapped onto physical spaces (Browne, Lim \& Brown). Queer spaces are not primarily physical spaces, they are created through spatial practices. Returning to Perrone's A Time Before Me for examples we see that a space that is a barn for animal bedding by day can become a gay bar (Bubba Joe's) by night because the men who meet there make it so. When Mason celebrates Decadence (a gay street spectacle which takes place on Labor Day weekend) in New Orleans, the public space of the street is queered. The public space of the street is subverted for a designated period of time and the queer child becomes the flâneur (Tribunella). The flâneur - like de Certeau's walker - is not merely an observer of life in the public domain, but is also an actant within that space. When Mason takes part in Decadence, he becomes one of the forces that temporarily change the public domain into a queer space. During the carnival, the dividing line between gay and straight is not policed. Mason watches as straight college boys cross the "invisible wall" and join in the parade: "I saw a few of them giving in to the Show Your Dick Brigade. Oddly enough, they seemed to be getting off on waving their dicks around for these gay men" (Perrone, 126). Yet, as Mikhail Bakhtin observed, carnival also has its rules, and these include limited duration. Indeed, all the queer spaces in this novel are marked by liminality.

Liminal spaces are in-between spaces. The street between home and school in Jason Donovan's I'll Get There (1969) lies beyond one threshold (home) but before entering into another, distinctly different, defined space (school). This is the space where Davy's relationship with Althusser can flourish, but it is also a place associated with risk. Davy's beloved dachshund, Fred, dies on the street when he is being walked by Davy's mother whilst Davy and his father discuss Davy and Althusser's relationship. In Davy's mind, Fred dies "Because of all that queering around" (Donovan, 185). The liminality may be temporal: during the day the park is a place for children to play, but at night it becomes a cruising ground. The temporality may be extended such as the temporary accommodation in Julie Anne Peters's Keeping You a Secret (2003), which is the only alternative to the risky space of the street available to the protagonist, Holland. Most of these spaces are associated with risk and typically deemed unsuitable for teenagers, not least because they are anonymous, public spaces, and in the novels I examined, they were exclusively urban spaces. 


\section{From Rural to Urban Environments}

A noticeable feature of the 40 Anglophone narratives was the transition from rural spaces to urban spaces. This is not an exclusively adolescent issue: Kath Weston drew attention to the stereotypical division of rural and urban "locates gay subjects in the city while putting their presence in the countryside under erasure" (262). In fiction for children and adolescents, however, the rural-urban divide is also used to symbolize growing up. There is a general tendency to depict young children against rural backdrops so as to emphasize Romantic connections between the child and nature, whereas the problem-based issues of teenage fiction are more likely to be set against realistic, urban backdrops (Natov). Queer spaces, in real life and in fiction, are predominantly urban, and their dissociation from nature inadvertently associates queer desires with the 'unnatural'. The movement from a rural environment to an urban environment reflects the real world situation in which queerly desiring individuals often move to live in regions such as the Castro in San Francisco where they do not need to explain themselves. In terms of the ideologies of childhood and adolescence, the movement also reflects a movement away from the idyll of childhood (associated with the natural world) towards the urbanity of adulthood.

This rural to urban move in search of a place one can call home is evident in M. E. Kerr's Deliver us from Evie (1994). Evie seems totally at home on her parents' farm surrounded by male farm workers, farm machinery, crops and livestock, but she must leave that space and move to the urban environment of New York City in order to be with her partner, Patsy. She is 'outed' by her brother Mason and Cord, a farm-worker who would like to marry Evie, and the community reacts badly. Although the novel ends on a moment of hope and reconciliation for the family members, the geographical locations cannot be reconciled. Evie who seemed so 'at home' on the farm is forced to live in an urban landscape, and her brother - who longed to leave the family farm - feels he will be trapped there forever.

Male teens do not fare better in rural environments. The freedom Mason experiences at Bubba Joe's only serves to make him find hiding his sexual orientation in his parents' home "tougher and tougher" (Perrone, 89). The liminality of the bar serves to heighten his awareness of risk in his everyday world; a world where he is afraid he may be beaten if he gets caught checking out a cute looking guy. Mason's decision to stay in New Orleans where his queer practices are less rigorously policed appears voluntary, but a closer reading 
reveals that his sexual orientation has limited the options he feels are available. He feels a strong need to stay close to established queer spaces, and so reorients his desires to keep himself in contact with those safe spaces. It is as though he cannot take his queerness with him into other spaces. More specifically, unlike the men interviewed for John Howard's Men Like That, Mason feels he cannot take his queerness into the rural spaces of Mississippi or his parents' home. ${ }^{2}$ In this respect, he is very much like Evie who must move to New York in order to 'do' her queerness. Both novels are hopeful, but nevertheless affirm that in order to find a space that feels like home, the queer youngster must leave the parental home space, leave rural spaces and enter an urban environment.

\section{Street life}

The urban environment is rarely welcoming for the characters in these Anglophone novels (a point Weston also noted in her study of adults). Not all the characters were as lucky as Mason in finding guides, and the novels act as guides in warning readers about some of the dangers they may face, especially on the street. As already noted, the entry and exit pints to the heterotopic spaces of gay districts are policed by both bouncers and self-appointed 'fag-bashers'. In Lennon's When Love Comes to Town (2003), Neil is badly beaten upon leaving a gay bar in Dublin's gay district. After his recovery, Neil is placed in a situation unrecognizable to a heterosexual teen: he must choose between pretending to be straight in order to remain in his parental home or leaving to find a queer space where he forge an independent life. Neil chooses the latter, but since he is still at school and so not financially independent, he turns to his summer romance, Shane. Unfortunately, Shane has decided to return to Belfast, leaving Neil's choices limited to the street and his parental home. He returns to his parents "But now Neil understands the conditions. We'll love you, providing you hide your love away. ... Just pretend" (190). Neil accepts the conditions: and accepts a half-life in return for shelter. Holland in Julie Anne Peters's Keeping You a Secret is - after a lengthy interval when she is homeless - offered the same choice as Neil. Although still in high school, Holland would rather remain physically unhomed than compromise her queerness and so rejects the offer.

When Holland's mother realises her daughter is lesbian, she physically threatens her and then throws her out of the house. When Holland attempts to return to collect her things, she finds that the locks 
have been changed: she has been unhomed. Given that queer adolescents are grossly over-represented in the homeless population ${ }^{3}$, Peters' depiction of this in a novel intended for this age group is refreshingly honest. Studies of homeless youths sometimes distinguish between 'runaways' (those who choose to leave their homes), 'throwaways' (those who are ejected from the family home) and those who are homeless along with their family. Although the numbers of queer adolescents who are runaways or throwaways are disproportionately high, queer teens are no more or less likely to be homeless along with their parents (Rosario, Schrimshaw and Hunter "Homelessness"). Corliss et al. found that 'conflicts with parents' was given as the main reason for $70 \%$ of homeless youths for leaving home (1683), and Rice et al found that queer adolescents were much more likely to report staying with a stranger and engaging in high risk sexual practices than heterosexual teens. The statistics captured in sociological data on orientation paint a distressing picture of queerly desiring teenagers floundering as they attempt to learn the spatial practices their sexual orientation demands, but which their parents cannot teach them. The figures for homeless youths may be shocking, but they come as no surprise to the queer community, each of whom has had to navigate their own route away from being assumed to be heterosexual towards the spatial as well as sexual practices that create the sense of being at home and the creation of a family that is not defined by biology.

Stunned to discover she has been locked out, Holland goes over to her girlfriend Cece's house, where she is made welcome. When Cece murmurs "You'll always have family now ... You're one of us" (Peters 194), she is referring to the sense of family that can come from belonging to a queer community. In her search for a home space, Holland and Cece seek help from their local GLBT center who find her a room in a boarding facility run by the local gay community. The door has a sign "SAFE SPACE" (195). This was the only instance of an overtly named spatial practice I found in the narratives, but this is what all the characters are seeking. A safe space which "shelters day-dreaming", a space which "protects the dreamer" (Bachelard, 6) which allows the adolescent to express his or her desires.

The room is well below the standards to which Holland is accustomed, but with the help from her new family and a good supply of cleaning fluids and elbow grease, the space is made tolerable, in part because it is expected to be temporary. Towards the end of the novel, Holland is offered the opportunity to return to the parental home. She accepts her mother's willingness to allow her to resume a rela- 
tionship with her baby half-sister, but declines the offer to return to a more comfortable space. The liminal space in the gay center is more 'home' than her mother's house. Holland's orientation is dependent upon how she resides in space (Ahmed, 1); the room in the refuge is a space where she can finally feel 'at home'.

\section{The Uncanny Adolescent}

In her search for a place where she can feel at home, Holland turns to the GLBT center. There, she is more than mildly disturbed to realize that she has been characterized as a 'street youth', an identity that seems wholly other.

Street youths? God. I never thought I'd be a street youth.

Syd got on the phone. It took her a while to find a place with an opening. Everywhere was full. There were waiting lists, which should've made me feel better, less alone. But it didn't. I just felt freaked. What if I ended up living on the street? (Peters, 196)

The idea of being a 'street youth' - an unhomed adolescent - 'freaks' middle class Holland: it is an identity she is unwilling to embrace, it is unheimlich.

The term unheimlich literally means 'unhomely' or 'not belonging to the home'. Etymologically the German term is associated with secrecy and privacy: that which should not be made public. In the Anglophone novels I examined, the liminal spaces in which teens could express same-sex desire became part of their identity. As a result, the unfortunate impression that the desires these characters expressed were also unheimlich was generated. Liminal spaces are often public spaces, and so desire performed in such spaces takes that which should be secret and private (desire) into public view, adding to the sense that such desires are unheimlich. When the term was used by Sigmund Freud in his 1919 essay 'Das Unheimliche' it was translated into English as 'The Uncanny', and it is in this sense with all its associations with the supernatural and unease - that the German term is used as a loanword in English. The uncanny is often associated with the supernatural, yet the roots of the term mean that it literally means 'that which is not known'.

Both uncanny and unheimlich rely on the expectation of the familiar and a sense of ill-ease when those expectations are not fulfilled. When adolescents express same-sex desire - come out - they are deemed unheimlich because they refute what Steven Bruhm and 
Natasha Hurley have identified as "a dominant narrative about children" namely that "children are (and should stay) innocent of sexual desires and intentions. At the same time, however, children are also officially, tacitly, assumed to be heterosexual" (ix). Unlike their heterosexual peers, queer teens are formulated as having undergone some form of transformation, as though they were heterosexual until they came out. Moreover, when teenagers reveal same-sex desires they incidentally force their parents into their own coming out process (as they must now reveal themselves to be the parents of a queer child). In the Anglophone narratives I examined, this seems to be where the problem lies. The uncanny (unknown) desires of the teen, seem unheimlich, and accepting those desires involves welcoming the unhomely into the private home space.

The forced ejection of teenagers like Holland and the seemingly voluntary departure from the family home by characters such as Evie and Mason signal premature entries into adulthood. For Evie and Mason, the need to earn a living in a place that feels like home results in the rejection of their previous goals. Their premature loss of a family home changes their lives forever. Holland, the youngest protagonist in the books mentioned here, is still at school when she is ejected from the family home. She struggles to combine the adult responsibilities of earning money, cooking and cleaning with her schoolwork. She manages only with the support from Cece and because she does not have to pay rent at the shelter. What we see in these novels is a limiting of the opportunities available to the queerly desiring teen. Holland, for instance, muses on the importance of Cece in her life: "Why did she make me feel like she was my mother and father and friend and lover all rolled into one? Because she was. She was my everything" (Peters, 202-3). Cece is too important to Holland. It may seem romantic, but it demands that Cece also take on adult responsibilities and both girls are placing their relationship and their sexual orientation at the forefront of their lives, whilst matters such as studying and careers take a back seat. Mason gives up the opportunity to study, Evie gives up a career in agriculture. Their lives are limited by the spaces in which they reside, the only spaces in which they can feel 'at home'.

In a survey of girls' culture in England 1880-1915, Sally Mitchell resists the tendency to read these works in terms of sexual repression. She notes that the Victorian assumption that adolescents were asexual allowed more scope "for self development and for vocational, mental, emotional, and intellectual independence" (Mitchell, 165). Paradoxically, she argues, the sexual libertarian attitudes of the third 
millennium has reduced girls' horizons and restricted their options; the world of the adolescent girl of the first decade of the 21st century revolves around 'catching' a man far more than it did for girls a century earlier. This is perhaps even more true for the queer adolescent whose identities seem to be dominated by their sexual orientation to the extent that careers, education and all other life choices are deemed secondary to finding a space in which they can feel at home with their same-sex desires.

\section{Make Yourself At Home!}

Home is the site in which children learn scripts for gendered, ethnic and other aspects of identity including the expression of desire. As a result, the sense of what it means to feel at home is not universal, but is dependent on a sense of match between expectations and behaviors. Literature plays a significant role in creating those expectations. As Mavis Reimer observes,

Learning to read 'home' matters. The homely imperatives adults direct to children through the texts designed for them proceed from determinate constructions of class, race, gender, and nation, and entail complicated understandings of the relation of self and other, kin and stranger, here and there. Learning to read 'home' matters: it is, perhaps, the beginning of rewriting it. (Home Words, xviii)

Reimer's early work reveals how diverse the concept of 'home' is, and her later work draws attention to children for whom "there is no place to call home" (No place, 1). In this article, I have highlighted the intersections between queer desires and the idea of 'home' to demonstrate how, for the queer teens in these Anglophone novels, the heterosexual home of origin is not a place to feel 'at home'.

The Anglophone narratives studied both reflect and promote real world attitudes towards queer teens. Unless their parents have been overtly pro-gay, teenagers are likely to have absorbed a great deal of homophobia from society and so fear their parents' reactions (Daniel and McEntire, 194). As a result, real life American gay and lesbian and teens are two to three times more likely to commit suicide than their heterosexual peers (Daniel and McEntire, 194). In the real world, homophobia kills. In fiction, the trope of associating death with same-sex desire is well-established (Cart and Jenkins, 84-5; Cart 77-9; Kokkola, 90-3), but rarely takes the form of suicide. As noted, the authors of these books clearly state their intention to offer readers 
the hope that it will get better. Rendering the queerly desiring teen unheimlich is undeniably a better option than suicide, but presenting a queer identity as paramount is problematic because of the way it limits the adolescents' life options. It is, as Reimer notes, time to begin the rewriting of such home scripts.

Biographical information: Lydia Kokkola is Professor of English and Education at Lulea University of Technology in northern Sweden. Her research interests include bilingual literacy education, Holocaust fiction, Adolescent Sexuality and she has just begun a new project on advanced reading skills. Her latest book, Fictions of Adolescent Carnality, was published by Benjamins (2013).

\section{Notes}

1 All the queer characters in the fiction I examined had heterosexual parents.

2 John Howard's Men Like That combines oral history with an extensive range of popular fiction to create a history of same-sex desire among men in postWorld War II Mississippi. Howard argues that 'southern indirection' - the reluctance to speak openly on topics deemed impolite - made it easier for men to engage in transgressive sexual activities. Although Howard does not discuss these activities in terms of spatial practices, he draws attention to the ways in which 'men like that' appropriated spaces such as the local waterhole, secluded woods, roadside rest areas, public restrooms, and even church recreation rooms for sex. These spaces, like Perrone's fictional bar, require the novice to learn the spatial practices which turn liminal, risky spaces into queer spaces where they can feel at home.

3 Drawing on an extensive number of surveys and other forms of data, Rosario, Schrimshaw and Hunter conclude that although LGB adolescents comprise only $1.4 \%-5.0 \%$ of the general population of teens in America, they comprise $15 \%-36 \%$ of homeless youth population ("Risk Factors").

\section{Works Cited}

\section{The Corpus of Novels and Short Stories for Teenagers}

Bauer, Marion Dane (ed.). Am I Blue? Coming Out from the Silence. New York: Harper Collins Publishers, 1994.

Block, Francesca Lia. Baby Be-Bop. New York: HarperCollins Publishers, 1995.

Block, Francesca Lia. Violet E Claire. New York: Joanna Cotler Books, 1999. 
Block, Francesca Lia. Weetzie Bat. New York: HarperCollins Publishers, 1989.

Boock, Paula. Dare Truth or Promise. Boston and New York: Graphia, 1997.

Chambers, Aidan. Dance on My Grave. London: The Bodley Head Children's Books, 1982.

Chambers, Aidan. Postcards from No Man's Land. London: Red Fox, [1999] 2001.

Chambers, Aidan. This Is All: The Pillow Book of Cordelia Kenn. London: Definitions, [2005] 2007.

Chbosky, Stephen. The Perks of Being a Wallflower. New York: Pocket Books, 1999.

Donovan, John. I'll Get There. It Better Be Worth the Trip. Woodbury, MN: Flux, [1969] 2010.

Duncan, Alasdair. Sushi Central. Brisbane: University of Queensland Press, 2003.

Ferris, Jean. Eight Seconds. Orlando, FL: Harcourt, Inc., 2000.

Frost, Helen. Keesha's House. New York: Farrar, Straus and Giroux, [2003] 2007.

Garden, Nancy. Annie on My Mind. New York: Aerial Fiction, [1982] 1992.

Garden, Nancy. Hear Us Out! New York: Farrar, Straus and Giroux, 2007.

Guy, Rosa. [1976]. Ruby. Harmondsworth: Penguin Books, 1989.

Hartinger, Brent. Geography Club. New York: HarperCollins, 2003.

Juby, Susan. Another Kind of Cowboy. New York: HarperTeen, 2007.

Kerr, M. E. [1994] Deliver Us From Evie. New York: Harper Trophy, 1995.

Kerr, M.E. “Hello," I Lied. New York: Harper Trophy, [1997] 1998.

Kerr. M. E. Little Little. New York: HarperCollins Publishers, 1981.

Knowles, John. A Separate Peace. New York: Bantam, 1959.

Koertge, Ron. The Arizona Kid. Somerville, MA: Candlewick Press, [1988] 2005. 
Lanagan, Margo. Touching Earth Lightly. St. Leonards, Australia: Allen \& Unwin, 1996.

Lennon, Tom. [1993]. When Love Comes to Town. Dublin: The O'Brien Press, 2003.

Levithan, David. The Lover's Dictionary. London: Fourth Estate, an imprint of HarperCollins, 2011.

Levithan, David. Boy Meets Boy. New York: Knopf Books for Young Readers, 2003.

Ness, Patrick. 2010. Different For Boys. In Gray, Keith (ed). 2010. Losing It. London: Andersen Press 71-117.

Perrone, Michael Holloway. [2005]. A Time Before Me. Lincoln, NE: iUniverse, 2008..

Peters, Julie Anne. [2003]. Keeping You a Secret. New York: Little, Brown and Company, 2005.

Peters, Julie Anne. Grl2grl: Short Fictions. New York: Hachette Book Group, 2007.

Ruditis, Paul. Rainbow Party. New York: Simon Pulse, 2005.

Sanchez, Alex. Rainbow Boys. New York: Simon and Schuster, 2001.

Sanchez, Alex. Rainbow High. New York: Simon and Schuster, 2003.

Sanchez, Alex. Rainbow Road. New York: Simon and Schuster, 2005.

Sanchez, Alex. Bait. New York: Simon and Schuster, 2009.

Sapphire. [1996] Push. New York: Vintage Books, 1997.

Springer, Nancy. The Boy on the Black Horse. New York: Atheneum Books for Young Readers, 1994.

Strelkoff, Tatiana. Allison: A Story of First Love. Dublin: The O'Brien Press, 1998.

Yates, Bart. Leave Myself Behind. New York: Kensington Books, 2003.

\section{Secondary Literature}

Abate, Michelle Anne. 2007. "An Interview with YA novelist M. E. Kerr." Children's Literature 37 (2007):191-197. Print.

Bachelard, Gaston. The Poetics of Space. [trans. Maria Jolas] Boston: Beacon Press, 1969. Print.

Bakhtin, Mikael. Rabelais and His World. Trans. Hélène Iswolsky. Bloomington: Indiana University Press, 1984. Print. 
Bergquist, Kathleen Ja Sook. “Once Upon a Time: A Critical Look at How Children's Literature Contextualizes Adoption for Asian Adoptees." In Bergquist K. J. S., M. E. Vonk, D. S. Kim and M. D. Feit (eds.). Transplanted Children: 50 years of Korean International Adoption. Binghamton, NY: Haworth Press. (2007). 295-313. Print.

Browne, Kath, Jason Lim and Gavin Brown (Eds.). Geographies of Sexualities: Theory, Practices and Politics. Farnhame, Surrey and Burlington, VT: Ashgate, 2009. Print.

Bruhm, Steven and Natasha Hurley (eds.). Curiouser: On the Queerness of Children. Minneapolis: Minnesota UP, 2004. Print.

Cart, Michael and Christine A. Jenkins. The Heart Has its Reasons: Young Adult Literature with Gay/Lesbian/Queer Content, 1969-2004. Maryland, Toronto \& Oxford: The Scarecrow Press, Inc., 2006. Print.

Cart, Michael. Gay and Lesbian Literature for Young Adults. Lanham, Maryland, Toronto \& Oxford: The Scarecrow Press, Inc., 2004. Print.

Corliss, Heather, Carol Goodenow, Lauren Nichols and Bryn Austin. "High Burden of Homelessness Among Sexual Minority Adolescents: Findings from a Representative Massachusetts High School Sample." American Journal of Public Health. 101 (2011) 9: 1683-1689. Print.

Daniel, Patricia L. and Vicki J. McEntire. "Rights of Passage: Preparing Gay and Lesbian Youth for Their Journey into Adulthood." In Kaywell, Joan F. (ed.). Using Literature to Help Troubled Teens Cope with Family Issues. Westport, CT and London: Greenwood Press. (1999). 193-224. Print.

de Certeau, Michel. The Practice of Everyday Life. Trans. Steven Rendall. Berkeley: University of California Press, 1984. Print.

Foucault, Michel. Of Other Spaces. Trans. Jay Miskowiec Diacritics 16 (1986) 1:22-27. Print.

Freud, Sigmund. "Das Unheimliche." [1919] 2010.

http:/ / www.gutenberg.org/files/34222/34222-h/34222-h.htm Web.

Halberstam, Judith. In a Queer Time and Place: Transgender Bodies, Subcultural Lives. NYU Press, 2005. Print.

Howard, John. Men Like That: A Southern Queer History. Chicago: University of Chicago Press, 1999. Print.

Kokkola, Lydia. Fictions of Adolescent Carnality: Sexy Sinners and Delinquent Deviants. Amsterdam and Philadelphia: John Benjamins Publishing Company, 2013. Print. 
Kokkola, Lydia. "Interpictorial Allusion and the Politics of 'Looking Like' in Allison and Emma's Rug by Allen Say." Children's Literature Association Quarterly. 35 (2011) 4: 47-63. Print.

Mitchell, Sally. The New Girl: Girl's Culture in England 1880-1915. New York: Columbia University Press, 1995. Print.

Natov, Roni. The Poetics of Childhood. New York and London: Routledge, 2003. Print.

Reimer, Mavis (Ed.). Home Words: Discourses of Children's Literature in Canada. Waterloo, Ontario: Wilfrid Laurier University Press, 2008. Print.

Reimer, Mavis. "'No Place like Home': The Facts and Figures of Homelessness in Contemporary Texts for Young People." Nordic Journal of ChildLit Aesthetics. 4 (2013) http://www.barnboken.net/ index.php/clr/article/view/21586 net.

Rice, Eric; Anamika Barman-Adhikari, Harmony Rhoades, Hailey Winetrobe, Anthony Fulginiti, Roee Astor, Jorge Montoya, Aaron Plant and Timothy Kordic. "Homelessness Experiences, Sexual Orientation, and Sexual Risk Taking Among High School Students in Los Angeles." Journal of Adolecent Health. 52 (2013):773-778. Print.

Rosario, Margaret, Eric Schrimshaw and Joyce Hunter. "Homelessness Among Lesbian, Gay, and Bisexual Youth: Implications for Subsequent Internalizing and Externalizing Symptoms." Journal of Youth Adolescence. 41 (2012):544-560. Print.

Rosario, Margaret, Eric Schrimshaw and Joyce Hunter. "Risk Factors for Homelessness among Lesbian, Gay, and Bisexual youths: A Developmental Milestone Approach." Children and Youth Services Review 34 (2012):186-193. Print.

Tribunella, Eric L. "Children's Literature and the Child Flâneur." Children's Literature. 38 (2010) 64-91. Print.

Trites, Roberta Seelinger. 2000. Disturbing the Universe: Power and Repression in Adolescent Literature. Iowa City: University of Iowa Press, 2000. Print.

Weston, Kath. "Get Thee to a Big City: Sexual Imaginary and the Great Gay Migration." GLQ: A Journal of Lesbian and Gay Studies 2.3 (1995): 253-277. Print. 